\title{
Impact of the Demographic Transition on Tax Collection in Brazil: an analysis of the federative aspect
}

\author{
Rafael Ferreira Tiné ${ }^{1}$ \\ Carlos Eduardo de Freitas ${ }^{2}$ \\ Nelson Leitão Paes ${ }^{3}$
}

\begin{abstract}
Several countries have been experiencing a process of population aging. In Brazil, this demographic process, according to Brazilian Institute of Geography and Statistics projections, reaching $24 \%$ in 2040 and $34 \%$ in 2060 . Thus, the present study innovates when proposing the evaluation of the impact of population aging on tax revenue, with special attention to the analysis of the impact on the collection of taxes on consumption, since the consumption basket tends to be different between young and old people. In order to do that, we use a 4-sector overlapping generation model (OLG) with 55 generations. The results suggest a reduction of output, consumption, working hours and investment. Tax revenues would fall more than output, with a larger reduction in consumption taxes. However, we observe that local revenue is less affected, due to the increase in the consumption of services, induced by the process of population ageing.
\end{abstract}

\section{Keywords}

Population aging. Overlapping generations model (OLG). Tax revenue.

\section{Resumo}

Vários países têm experimentado um processo de envelhecimento da população. No Brasil, esse processo demográfico, segundo projeções do Instituto Brasileiro de Geografia e Estatística, chega a 24\% em 2040 e 34\% em 2060. Assim, o presente estudo inova ao propor a avaliação do impacto do envelhecimento populacional sobre a receita tributária, com especial atenção à análise do impacto na cobrança de impostos sobre o consumo, uma vez que a cesta de consumo tende a ser diferente entre jovens e idosos. Para isso, usamos um modelo de geração com sobreposição de 4 setores (OLG) com 55 gerações. Os resultados sugerem redução

$1 \mathrm{PhD}$, Analista - Banco Central do Brasil - Endereço: Setor Bancário Sul (SBS), Quadra 3 Bloco B - Ed. Sede - Brasília/DF - Brasil - CEP: 70074-900 - E-mail: rafaeltine@hotmail.com. ORCiD: https://orcid.org/0000-0003-1362-5459.

2 Professor - Universidade Federal de Rondonópolis (UFR-FACAP) - Endereço: Av. dos Estudantes, 5055 - Cidade Universitária - Rondonópolis - Mato Grosso/MT - Brasil - CEP: 78735-901. E-mail: cefreitas@ufmt.br - ORCiD: https://orcid.org/0000-0002-6347-011X.

3 Professor - Universidade Federal de Pernambuco (UFPE-PIMES) - Endereço: Av. Prof. Moraes Rego, 1235 - Cidade Universitária - Recife/PE - Brasil - CEP: 50670-420 - E-mail: nlpaes@gmail.com. ORCiD: http://orcid.org/0000-0001-6246-4503.

Recebido: 20/03/2019. Aceite: 31/12/2019.

Editor Responsável: Rafael Terra de Menezes

(c) (i) (\$) Esta obra está licenciada com uma Licença Creative Commons Atribuição-Não Comercial 4.0 Internacional. 
de produção, consumo, trabalho e investimentos. As receitas fiscais cairiam mais do que a produção, com uma redução maior nos impostos sobre o consumo. No entanto, observa-se que a receita local é menos afetada, devido ao aumento do consumo de serviços, induzido pelo processo de envelhecimento populacional.

\section{Palavras-Chave}

Envelhecimento da população. Modelo de gerações sobrepostas (OLG). Receita fiscal.

\section{JEL Classification}

J11. H2O. H77.

\section{Introduction}

The world population is expected to raise from 1 billion to 10 billion people between 1800 and 2100, reflecting the intense demographic transition that has taken place in recent centuries. The reduction of the mortality rate started the first phase of the process, intensifying the population growth with great participation of children. Then the fertility rate decreased which reduced the rate of population growth and concentrated the population at the active age. The process, although at different stages between countries, is in its third phase, where mortality and fertility rates stabilize at a low level, and the elderly have a greater representation in the population.

In Brazil, the population aging stage is in its infancy, so that the proportion of the population aged 60 years or more increased from $8.2 \%$ in 2000 to $11 \%$ in 2013 . This rate is still well below that of developed regions in the same year, 23\%. However, according to Brazilian Institute of Geography and Statistics (IBGE) projections, the aging process will be intensified, reaching 24\% in 2040 and 34\% in 2060 (IBGE 2013).

The second phase of the demographic transition is often related to the existence of a "demographic bonus", represented by the concentration of the largest portion of the population in the active age. Following the logic of life-cycle theory of consumption, many experts argue that the greater proportion of people in the working age tends to increase aggregate savings, boosting economic growth. The reason is that in this age group the savings rate is higher. 
Following this idea, many studies, such as Bloom and Williamson (1998) and Bloom and Finlay (2009), pointed to the possibility of a reversal in the "demographic bonus" in the third stage of the transition, in which the smaller fraction of the working age population would have a negative impact on the aggregate saving rate, reducing economic growth.

In addition to the impact on growth, the demographic transition process also brings about relevant changes in the country's fiscal situation, as it tends to change the structure of government revenues and expenditures. These changes, in turn, affect economic growth. Due to this interrelationship, the use of dynamic models was intensified to try to capture all these effects, of which the work of Auerbach and Kotikof (1987) is the greatest example.

Fehr et al. (2008) analyzed the effects of aging in the economies of the United States, Japan and the European Union. Results are similar to those already found in the literature - aging leads to a large increase in taxes on the payroll for social security. Another example is the study by Kudrna et al. (2014). The authors analyzed the tax implications of demographic change in Australia. With the process of population aging, there would be a shift of the tax basis from labor income to consumption and capital income, as well as a substantial increase in expenditures on programs related to the elderly. To finance these expenses, a $28 \%$ increase in the consumption tax rate would be necessary.

Although pensions are the most analyzed program due to their weight in public spending and the direct impact that aging populations must have on their account, it is important to analyze the various fiscal aspects of the situation. Thus, the present study innovates when proposing the evaluation of the impact of population aging on tax revenue, with special attention to the analysis of the impact on the collection of taxes on consumption, since the consumption basket tends to be different between young and old people.

It is important to mention that population aging is accompanied by large fiscal constraints in Brazil. Even with a relatively young population, the country spends the equivalent of $13 \%$ of GDP on pensions. This figure is more than twice what countries with similar proportions of the elderly (6.3\%) spend on these programs (Standard \& Poors 2016). The same pub- 
lication estimates that this expenditure will rise to $16.8 \%$ of GDP in 2030 and $25.6 \%$ of GDP in 2060.

The differentiation in revenues between government levels will be taken into account in the analysis, in order to advance in a relevant theme of the Brazilian fiscal reality. Since Brazil has the particularity of concentrating the taxation on services in the municipal level while States have as main source of revenue the taxation on goods, there is a tendency of strengthening the collection of the municipalities and weakening of the collection of the states, reinforcing a process which has been verified in recent years. The analysis will be carried out through a dynamic model of overlapping generations (OLG) with four sectors of the economy: households, firms, government and social security. It was admitted that the current social security rules remain valid indefinitely. We are not simulating any pension reform.

The results confirm that the effect on the collection would happen in a different way in each government level. State revenue would be the biggest drop, while the impact on municipal revenue would be much less intense. The strong concentration of state revenue in a tax on consumption of goods determines this result, since in addition to reducing consumption, it is expected that the share of goods in household consumption will decrease due to aging, in contrast to the participation of services, which increase.

In addition to this introduction, the study will be structured in six other sections. In the next section, the economic model will be presented and in the third section the model is calibrated. In the fourth section, we present the simulation to be performed, through the changes in the population parameter, with the results discussed in the next section. Finally, the main conclusions of the study are presented.

\section{Model}

For the analysis of the tax impact of the demographic transition in Brazil, a model of overlapping generations with 55 generations was built with a representative firm and three levels of government. 


\subsection{Households}

Each generation lives 55 periods and it is useful to think that the agents start working at age 21 (when $j=1$, where $j$ is the generation), retire at 55 years of age $(j=35)$, and die at 75 years of age $(j=55)$. Each year, one generation dies and another takes its place. The uncertainty was considered in the model by means of the mortality rate of each family, represented by the conditional probability of each generation to live another year (Freitas 2015).

Families choose current and future levels of consumption and leisure according to their income expectations throughout their lives. Individual preferences are formed for each generation at each point in time and are represented by a constant elasticity of substitution (CES) function. In this way, the intertemporal utility function can be represented as follows:

$$
\begin{aligned}
& U_{t}=\frac{1}{1-\frac{1}{\gamma}} \sum_{j=1}^{55}(1+\beta)^{(1-t)} p_{j} u_{j, t}{ }^{\left(1-\frac{1}{\gamma}\right)} \\
& u_{j, t}\left(c_{j, t}, l_{j, t}\right)=\left(c_{j, t}\left(1-\frac{1}{\rho}\right)+\alpha l_{j, t}\left(1-\frac{1}{\rho}\right)\right) \frac{1}{\left(1-\frac{1}{\rho}\right)}
\end{aligned}
$$

Where $\gamma$ is the intertemporal substitution elasticity, $\beta$ is the discount rate, $p_{j}$ is the probability of the family living $j$ periods. The variables $c_{j, t}$ and $l_{j, t}$ represent consumption and leisure for generation $j$ at time $t$. The parameter $\rho$ represents the intratemporal substitution elasticity between consumption and leisure and $\alpha$ is the households' preferences for leisure in relation to consumption.

Households maximize their intertemporal utility based on their income expectations throughout the life cycle:

$$
\max _{\left\{c_{j, t,}, l_{j, t}\right\}} U_{t}=\frac{1}{1-\frac{1}{\gamma}} \sum_{j=1}^{55}(1+\beta)^{-(t-1)} p_{j} u_{j, t}{ }^{\left(1-\frac{1}{\gamma}\right)}
$$


Subject to budget constraint:

$$
\begin{gathered}
\sum_{j=1}^{35}\left\{\left(W_{t} e_{j}\left(1-l_{j, t}\right)\left(1-\tau_{l t}-\tau_{s t}\right)\right) \prod_{m=1}^{t}\left[1+r_{m}\left(1-\tau_{k t}\right)\right]^{-1}\right\}+ \\
\sum_{j=36}^{55}\left\{\left(b_{t}+T r_{t}\right) \prod_{m=36}^{t}\left[1+r_{m}\left(1-\tau_{k t}\right)\right]^{-1}\right\} \geq \sum_{j=1}^{55}\left\{\left(\left(1+\tau_{c t}\right) c_{j, t}\right) \prod_{m=1}^{t}\left[1+r_{m}\left(1-\tau_{k t}\right)\right]^{-1}\right\} \\
l_{t}<1, \forall t=1, \ldots, 35 . \\
l_{t}=1, \forall t=36, \ldots, 55 .
\end{gathered}
$$

The variable $W t$ is the rate of wages in year $t,\left(1-l_{j, t}\right)$ is the hours worked and $e_{j}$ is an adjustment factor that represents differences in skill levels between families of different ages, allowing the possibility of which different families earn more or less per hour in year t. One can think of the vector $e_{j}$ as a proxy for "human capital". The tax rates are: $\tau_{l t}-\operatorname{tax}$ rate on labor income, $\tau_{k t}$ - rate on capital income, $\tau_{c t}$ - consumption tax rate and $\tau_{s t}$ - social security tax rate, and $T r_{t}$ are government transfers.

Note that in the model, income tax does not apply to pensions, while Brazilian law mandates the collection of income tax on pensions that exceeds the exemption limit. However, the vast majority of social security benefits are below this limit. For simplicity and difficulty in obtaining detailed data on the portion of social security benefits that are subject to income tax, the choice of modeling was to exclude these benefits from the income tax base.

The real interest rate is represented by $r_{t}$ and $b_{t}$ is the value of pensions. According to Law $n^{\circ}$. 8.213, retirees by contribution time and by age will have their benefits calculated as a simple arithmetic mean of the eighty percent highest contribution salaries of the entire contributory period. In order to approximate what is established by law, the social security benefit in this study is calculated as follows:

$$
b_{t}=0,8 \sum_{j=1}^{45}\left(\frac{W_{t} e_{j}\left(1-l_{j, t}\right)}{45}\right) f
$$

Where $f$ is a constant related to the replacement rate. Solving the maximization of the utility function subject to the budget constraint for $j=1, \ldots, 35$, we obtain the intertemporal trajectories and the intratemporal relation of consumption and leisure: 


$$
\begin{aligned}
& c_{j, t}=c_{j-1, t-1} \cdot\left(\frac{(1+\beta)^{t-2}}{(1+\beta)^{t-1}}\right)^{\gamma} \cdot\left(\left[1+r_{t} \cdot\left(1-\tau_{k t}\right)\right]\right)^{\gamma} \cdot\left(\frac{P_{j}}{P_{j-1}}\right)^{\gamma} \\
& \cdot\left(\frac{1+\tau_{c t-1}}{1+\tau_{c t}}\right)^{\gamma} \cdot\left(\frac{1+\alpha^{\rho}\left(w_{j-1, t-1}^{*}\right)^{(1-\rho)}}{1+\alpha^{\rho}\left(w_{j, t}^{*}\right)^{(1-\rho)}}\right)^{\frac{\rho-\gamma}{\rho-1}} \\
& l_{j, t}=l_{j-1, t-1} \cdot\left(\frac{(1+\beta)^{t-2}}{(1+\beta)^{t-1}}\right)^{\gamma} \cdot\left(\left[1+r_{t} \cdot\left(1-\tau_{k t}\right)\right]\right)^{\gamma} \cdot\left(\frac{P_{j}}{P_{j-1}}\right)^{\gamma} \\
& \cdot\left(\frac{1+\tau_{c t-1}}{1+\tau_{c t}}\right)^{\gamma} \cdot\left(\frac{1+\alpha^{1+\rho}\left(w_{j-1, t-1}^{*}\right)^{(1-\rho)}}{1+\alpha^{1+\rho}\left(w_{j, t}^{*}\right)^{(1-\rho)}}\right)^{\frac{\rho-\gamma}{\rho-1}} \\
& \cdot\left(\frac{w_{j-1, t-1}^{*}}{w_{j, t}^{*}}\right)^{\rho} \\
& l_{j, t=} c_{j, t} \alpha^{\rho} w_{j, t}^{*-\rho}
\end{aligned}
$$

Where:

$$
w_{j, t}^{*}=\frac{W_{j, t} e_{j}\left(1-\tau_{l t}-\tau_{s t}\right)+\mu_{j, t}}{\left(1+\tau_{c t}\right)}
$$

The parameter $\mu_{j, t}$ represents the shadow wage of the family $j$ in year $t$, which is different from zero if the individual decides not to work and is equal to zero if she offers any labor amount in year $t$. The ratio $\frac{P_{j}}{P_{j-1}}$ is the conditional probability of a family of the generation already living plus a unit of time.

The leisure trajectory is unitary for retirees, who correspond to the ages $j=36, \ldots, 55$. Thus, we obtain the following consumption equation for the retirees resulting from the process of maximizing the utility function subject to the budget constraint: 


$$
\begin{aligned}
& \left(\frac{c_{j, t}}{c_{j-1, t-1}}\right)^{-\left(\frac{1}{\rho}\right)}\left(\frac{c_{j, t}^{\left(1-\frac{1}{\rho}\right)}+\alpha l_{j, t}^{\left(1-\frac{1}{\rho}\right)}}{c_{j-1, t-1}^{\left(1-\frac{1}{\rho}\right)}+\alpha l_{j-1, t-1}^{\left(1-\frac{1}{\rho}\right)}}\right)^{\left(\frac{\frac{1}{\rho}-\frac{1}{\gamma}}{1-\frac{1}{\rho}}\right)} \\
& =\left(\frac{(1+\beta)^{-(t-2)}}{\left[1+r_{t}\left(1-\tau_{k t}\right)\right](1+\beta)^{-(t-1)}}\right)\left(\frac{P_{j-1, t-1}}{P_{j, t}}\right)\left(\frac{1+\tau_{c t}}{1+\tau_{c t-1}}\right)
\end{aligned}
$$

\subsection{Firms}

There is a representative firm that behaves competitively. The production function follows a Cobb-Douglas technology, with capital and labor as input. The level of efficiency $\left(e_{j}\right)$ differentiates the work, that is, people of different ages provide different amounts of efficient labor. Capital is homogeneous, so the production function is described as follows:

$$
Y_{t}=F\left(K_{t}, L_{t}\right)=A_{t}\left(K_{t}^{\theta}, L_{t}^{1-\theta}\right)
$$

Where $Y_{t}$ is the aggregate output, $K_{t}$ and $L_{t}$ represent capital and aggregate labor, respectively. The parameter $\theta$ is the share of capital income in the production function and $A_{t}$ represents the total productivity of the factors.

Choosing to model with only one representative firm means that the model cannot take into account that the service sector may be more capital intensive than the goods sector. The reason for the choice is to keep the model numerically tractable. Allowing the presence of two representative firms in the model would lead to a substantial increase in the number of nonlinear equations for a solution with transition between two steady states.

Firms maximize profits, given the costs of production factors, as follows:

$$
\Pi_{t}=Y_{t}-w_{t} L_{t}-\left(r_{t}+\delta\right) K_{t}
$$

The rate of capital depreciation is represented by $\delta$. From the problem of maximization of firms: 


$$
\begin{aligned}
& W_{t}=(1-\theta) A_{t}\left(\frac{K_{t}}{L_{t}}\right)^{\theta} \\
& r_{t}=\theta A_{t}\left(\frac{K_{t}}{L_{t}}\right)^{\theta-1}-\delta
\end{aligned}
$$

\subsection{Government}

The government consumes goods and services and is financed by tax revenues, less social security and government transfers. Government consumption is represented as follows:

$$
G_{t}=T_{t}-S_{t}^{B}-T r_{t}
$$

Where $G_{t}$ is the government consumption of goods and services, $S_{t}^{B}$ are the benefits of social security and $T r_{t}$ are government transfers. The variable $T_{t}$ is the tax revenues:

$$
\begin{aligned}
T_{t}=\sum_{j=1}^{35} N_{j, t} \tau_{l j} & W_{t} e_{j}\left(1-l_{j, t}\right) \\
& +\sum_{j=1}^{55}\left(N_{j, t} c_{j, t} \tau_{c f t}+N_{j, t} \omega_{j} c_{j, t} \tau_{c e t}+N_{j, t}\left(1-\omega_{j}\right) c_{j, t} \tau_{c m t}\right) \\
& +\left(\tau_{k f t}+\tau_{k e t}+\tau_{k m t}\right)\left(r_{t}+\delta\right) K_{t}+S_{t}^{A}
\end{aligned}
$$

Where $S_{t}^{A}$ is the social security revenue, $N_{j, t}$ is the population of generation $j$ referring to year $t$. The variable $\omega_{j}$ is the proportion of goods in the total consumption of each generation, while the complement $\left(1-\omega_{j}\right)$ represents the proportion of services. Taxes on consumption and capital are shared among the three government levels. The indices ' $f$ ', ' $e$ ', ' $m$ ' in the rate of these taxes represent, respectively, federal, state and municipal levels. 


\subsection{Social Security}

The social security system uses the pay-as-you-go system (PAYG), in which benefits, $b_{t}$, received from 56 years of age (in the model equals to $j=$ 36 ) up to 75 years of age (in model $j=55$ ), are an average of the contribution wages of each individual.

The total annual expenditure on social security can then be represented by the following equation:

$$
S_{t}^{B}=\sum_{j=36}^{55} N_{j, t} b_{t}
$$

The annual revenue of the social security comes from the salary of employees weighted by the hours worked and by the human capital proxy $\left(e_{j}\right)$ :

$$
S_{t}^{A}=\sum_{j=1}^{35} N_{j, t} W e_{j}\left(1-l_{j, t}\right)\left(\tau_{s f}+\tau_{s e}+\tau_{s m}\right)
$$

\subsection{Market Equilibrium}

The equilibrium conditions must be satisfied for each of the markets:

$$
\begin{aligned}
C_{t} & =\sum_{j=1}^{55} c_{j, t} N_{j, t} \\
L_{t} & =\sum_{j=1}^{35} N_{j, t} e_{j}\left(1-l_{t, j}\right) \\
Y_{t} & =C_{t}+I_{t}+G_{t}
\end{aligned}
$$

Where,

$$
I_{t}=K_{t+1}-(1-\delta) K_{t}
$$




\subsection{Model Solution}

The equilibrium system can be characterized by Equations (6) to (8), (10), (13), (14) and (15) to (21). The resulting set of nonlinear dynamic equations was solved by an algorithm developed by Broyden (1965).

\section{Calibration}

The calibration was built based on the economic data of 2013. For the macroeconomic aggregates, the National Accounts released by the IBGE, estimate household consumption, government consumption and investment, all in proportion to GDP, at $60.18 \%, 18.95 \%$ and $20.86 \%$, respectively.

The share of labor income, also withdrawn from the National Accounts, was $61.8 \%$ of GDP. The real interest rate was calculated at $2.28 \%{ }^{1}$ The revenue data was obtained from the Brazilian Federal Revenue Service (RFB 2014) and social security expenditure was obtained from the Statistical Yearbook of Social Security (MPS 2014).

The capital stock was calculated by the equation $\bar{K}=\frac{\theta}{r}$, while the depreciation was obtained by the equation $\delta=\frac{\bar{I}}{\bar{K}}$. Working hours were estimated as the ratio of the legal workweek in Brazil of 44 hours divided by the total hours available per week $(168-56=112 \mathrm{~h})$.

Table 1 - Macroeconomic Aggregates - 2013

\begin{tabular}{lclc}
\hline Variable & Value & Variable & Value \\
\hline Consumption (\% of GDP) & 60.18 & Federal Revenues (\% of GDP) & 24.18 \\
Government Consumption (\% of GDP) & 18.95 & States Revenues (\% of GDP) & 8.45 \\
Capital Stock (\% of GDP) & 760.33 & Municipals Revenues (\% of GDP) & 1.86 \\
Investment (\% of GDP) & 20.86 & Social Security Revenues (\% of GDP) & 7.15 \\
Real Interest Rate (\%) & 2.28 & Social Security Expenditure (\% of GDP) & 10.92 \\
Share of labor Income (\% of GDP) & 61.80 & Depreciation (\%) & 2.70 \\
Working Hours & 0.3928 & & \\
\hline
\end{tabular}

Source: IBGE (2014) and RFB (2014).

1 The Selic interest rate, as an average of the last six months of 2013, reached 9.19\%; from this interest rate, the accumulated inflation of the period was discounted based on Índice Nacional de Preços ao Consumidor Amplo (IPCA - Broad National Consumer Price Index): 5.91\%, reaching a real interest rate of $3.28 \%$ per annum (a.a.). 
Some parameters were taken from the literature. The elasticity of intertemporal substitution, $\gamma$, was set at 0.7 following Cavalcanti (2010) and the preference parameter for leisure in the utility function, $\alpha=0,25$, taken from Cavalcanti and Silva (2010). The intertemporal substitution elasticity, $\rho=1,134$, the intertemporal discount rate, $\beta=0,025$ and the total factor productivity, $A=0,821$, were calculated by Equations (6), (8) and (11), respectively. Regarding the adjustment factor for the skill levels of each family $j$, it was calculated by the following formula $e_{j}=e^{\left(a+b j+c j^{2}\right)}$. The values of the parameters $a=0.94410, b=0.024118$ and $c=-0.000671$ were taken from Cavalcanti and Silva (2010).

The tax rates were calculated following the methodology proposed in Paes and Bugarin (2006). The taxes were obtained by tax base and by level of government. Table 2 presents the results.

Table 2 - Tax Rates

\begin{tabular}{lcc}
\hline Variable & Description & Value \\
\hline$\tau_{k f}$ & Tax rate on Capital Income - federal & $\tau_{k f}=0,125$ \\
$\tau_{k e}$ & Tax rate on Capital Income - states & $\tau_{k e}=0,016$ \\
$\tau_{k m}$ & Tax rate on Capital Income - municipalities & $\tau_{k m}=0,019$ \\
$\tau_{l}$ & Tax rate on Labor Income - only federal & $\tau_{l}=0,107$ \\
$\tau_{s f}$ & Social Security Tax Rate - federal & $\tau_{s f}=0,1078$ \\
$\tau_{s e}$ & Social Security Tax Rate - states & $\tau_{s e}=0,0053$ \\
$\tau_{s m}$ & Social Security Tax Rate - municipalities & $\tau_{s m}=0,0026$ \\
$\tau_{c f}$ & Tax Rate on Consumption - federal & $\tau_{c f}=0,1007$ \\
$\tau_{c e}$ & Tax Rate on Consumption - states & $\tau_{c e}=0,19$ \\
$\tau_{c m}$ & Tax Rate on Consumption - municipalities & $\tau_{c m}=0,04$ \\
\hline
\end{tabular}

Source: IBGE (2014) e RFB (2014).

The share of services in total consumption, $\left(1-\omega_{j}\right)$, was estimated based on the proportion of service consumption of each generation, obtained from the Family Budget Survey 2008-2009 (POF 2008-2009), carried out by IBGE with a sample of 55,970 units of consumption. The age of the head of the unit of consumption defines the insertion of the family in each generation. 
The first step was to separate what is consumption of goods from consumption of services for tax purposes. Services are taxed by a municipal tax - ISS ${ }^{2}$ while goods are taxed by a state tax - ICMS. ${ }^{3}$ All services subject to ISS incidence, as determined by Complementary Law $n^{\circ} 116$, were classified as services in the calibration of $\left(1-\omega_{j}\right)$. The rest of the consumption basket of each family was classified as goods. ${ }^{4}$

The units of consumption were divided into 11 groups according to the age of their head. The results were as follows:

Table 3 - Share of Goods and Services in Consumption Basket by Age

\begin{tabular}{cccccc}
\hline Age Group & $\begin{array}{c}\text { Share of } \\
\text { Goods }\end{array}$ & $\begin{array}{c}\text { Share of } \\
\text { Services }\end{array}$ & Age Group & $\begin{array}{c}\text { Share of } \\
\text { Goods }\end{array}$ & $\begin{array}{c}\text { Share of } \\
\text { Services }\end{array}$ \\
\hline $21-25$ & $69.6 \%$ & $30.4 \%$ & $51-55$ & $62.6 \%$ & $37.4 \%$ \\
$26-30$ & $69.4 \%$ & $30.6 \%$ & $56-60$ & $64.1 \%$ & $35.9 \%$ \\
$31-35$ & $68.4 \%$ & $31.6 \%$ & $61-65$ & $61.2 \%$ & $38.8 \%$ \\
$36-40$ & $64.6 \%$ & $35.4 \%$ & $66-70$ & $62.7 \%$ & $37.3 \%$ \\
$41-45$ & $64.1 \%$ & $35.9 \%$ & $71+$ & $60.7 \%$ & $39.3 \%$ \\
$46-50$ & $63.7 \%$ & $36.3 \%$ & Average & $64.5 \%$ & $35.5 \%$ \\
\hline
\end{tabular}

Source: Authors' Elaboration.

An important limitation is that the calibration of consumer basket does not fully address the fact that service participation tends to increase with income. To some extent, this was taken into account. The participation of services by generation was taken from POF based on the age of the head of household. The same POF indicates that income increases with age. Thus, the calibration of the share of services in the consumption basket of each generation eventually took into account, not only a question of older people's preference for services over younger ones, but also the fact that people have their incomes raised as they get older.

To calculate the parameter $\omega_{j}$ for each of the 55 generations, the value obtained for each age group was assigned to the median age of the group (for example, 23 years in the group of 21 to 25 years). For other ages it was carried out a linear interpolation of the values shown above.

2 Imposto sobre Serviços

3 Imposto sobre a Circulação de Mercadorias e Serviços

4 Annex 1 presents the table used for the correspondence between services listed in the POF and those listed in Complementary Law $n^{\circ} 116$. 
Finally, $\frac{P_{j}}{P_{j-1}}$ represents the conditional probability of a family of the generation $j$ lives another period. The values of such probability were extracted from IBGE projections (IBGE 2013).

\section{Simulations}

This article simulates the effects of the change in population distribution, $N_{t, j}$ in time. In order to carry out such a simulation, we used the population data projected by IBGE in the publication "Projeções da População - Brasil e Unidades da Federação" (IBGE 2013). The projection of IBGE is carried out until the year 2060, after that period it is considered that there will be no further demographic changes.

An indicator widely used in the literature is the old-age dependency ratio, which represents the ratio of retirees to the working age population. In this paper, individuals start working at age 21 and retire at age 56 , so the old-age dependency ratio is measured as the relationship between people aged 56 years and over in relation to those between 21 and 55 years. The next table shows that this ratio increases between 2013 and 2060 .

Table 4 - Distribution of the Population by Age Groups (\%)

\begin{tabular}{cccccccccccc}
\hline Age Groups & $\mathbf{2 1 - 2 5}$ & $\mathbf{2 6 - 3 0}$ & $\mathbf{3 1 - 3 5}$ & $\mathbf{3 6 - 4 0}$ & $\mathbf{4 1 - 4 5}$ & $\mathbf{4 6 - 5 0}$ & $\mathbf{5 1 - 5 5}$ & $\mathbf{5 6 - 6 0}$ & $\mathbf{6 1 - 6 5}$ & $\mathbf{6 6 - 7 0}$ & $\mathbf{+ 7 1}$ \\
\hline 2013 & 13.5 & 13.9 & 13.2 & 11.6 & 10.5 & 9.7 & 8.5 & 6.9 & 5.4 & 3.9 & 2.8 \\
2040 & 8.7 & 9.2 & 9.8 & 10.3 & 10.3 & 10.2 & 10.1 & 10.0 & 8.5 & 7.1 & 5.9 \\
2060 & 7.6 & 7.9 & 8.3 & 8.7 & 9.1 & 9.6 & 10.1 & 10.4 & 10.1 & 9.5 & 8.7 \\
\hline
\end{tabular}

Source: Authors' Elaboration.

The old-age dependency ratio, which was 0.23 in 2013, rise to 0.46 in 2040. In 2060 the dependency ratio jumps to 0.60, characterizing the acceleration of the aging process. In 2060 the group of the retirees represents 39\% of the population, while the share of young workers (21-35) continues to fall (24\%) and the share of middle-age workers (36-55) starts to decrease $(37 \%)$. 


\section{Results}

The simulation was carried out for a period of 150 periods, since the literature indicates that the suggested period for the convergence of overlapping generation models would be between two and three times the number of generations considered (Auerbach and Kotlikoff 1987).

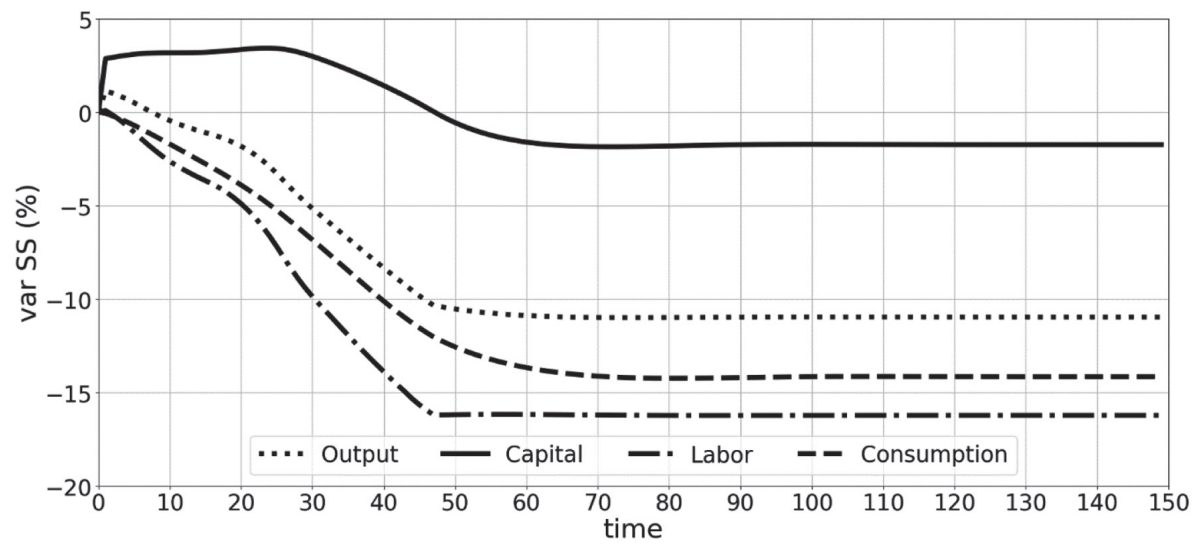

Figure 1 - Transition trajectories of the selected variables (percentage variation in relation to the initial steady state)

Source: Authors' Elaboration.

Capital and labor are reduced inducing the fall of output. However, labor decreases more than capital. As a consequence of the increase in the capital-labor ratio, there is a reduction in the interest rate and an increase in wages. Consumption, in turn, shows a more intense reduction than that verified by the output.

The increase in the old-age dependency ratio since the beginning of the demographic transition directly affects the aggregate labor supply. Although there is an increase in the supply of labor by agents, the composition effect dominates, determining the fall in aggregate labor.

Although the proportion of people of working age declines during the entire transition, the composition of this group changes in the period. The proportion of young workers is reduced, but middle-aged workers become more representative in 2040. According to the life-cycle theory, indivi- 
duals accumulate assets, especially in middle age, to satisfy the need for post-retirement consumption.

Thus, the higher proportion of middle-aged workers represents a greater accumulation of capital. In addition, agents change their behavior due to population aging and falling interest rates and subsequent wage increases. As a result, families choose to increase labor supply and reduce consumption, which stimulates even more the capital accumulation movement at the beginning of the transition. Consequently, aggregate investment rises 2\% from 2013 to 2040, as can be seen in Table 5 .

Table 5 - Impacts of the Demographic Transition on Macroeconomic Variables and Revenues

\begin{tabular}{|c|c|c|c|c|c|}
\hline \multirow[t]{2}{*}{ Variable } & \multirow{2}{*}{$\begin{array}{c}2013 \\
\% \text { GDP }\end{array}$} & \multicolumn{2}{|c|}{2040} & \multicolumn{2}{|c|}{2060} \\
\hline & & $\%$ GDP & S.S* & $\%$ GDP & S.S \\
\hline \multicolumn{6}{|l|}{ Macroeconomic Aggregates } \\
\hline - Output (Y) & 100 & 100 & -8.1 & 100 & -10.9 \\
\hline - Private Consumption & 60.2 & 59.0 & -10.0 & 58.2 & -13.8 \\
\hline - Public Consumption & 18.9 & 18.9 & -7.9 & 18.9 & -10.6 \\
\hline - Investment & 20.8 & 23.0 & 1.4 & 23.0 & -1.4 \\
\hline \multicolumn{6}{|l|}{ Tax Revenues } \\
\hline - Total (including Social Security) & 34.5 & 34.3 & -9.0 & 33.9 & -12.5 \\
\hline - Labor Income & 6.6 & 6.5 & -9.1 & 6.5 & -12.1 \\
\hline - Consumption & 15.3 & 14.9 & -10.5 & 14.8 & -13.7 \\
\hline - Capital Income & 5.5 & 5.4 & -9.1 & 5.4 & -12.7 \\
\hline \multicolumn{6}{|l|}{ Social Security } \\
\hline - Revenues & 7.1 & 7.1 & -8.5 & 7.1 & -11.3 \\
\hline - Benefits & 10.9 & 24.0 & 102.8 & 27.2 & 122.0 \\
\hline \multicolumn{6}{|l|}{ Revenues by Government Units } \\
\hline - Federal Revenues & 24.2 & 24.0 & -8.7 & 23.9 & -12.0 \\
\hline - State Revenues & 8.4 & 8.2 & -10.7 & 8.1 & -14.3 \\
\hline - Local Revenues & 1.9 & 1.9 & -10.5 & 1.8 & -15.8 \\
\hline
\end{tabular}

Source: Authors' Elaboration. ${ }^{*}$ percentage change from steady state (2013). 
This result is similar to that obtained by Auerbach and Kotikof (1987), Bloom and Williamson (1998) and Bloom and Finlay (2009), who found that in the second phase of the demographic transition, in the face of a longer life expectancy, the level of savings increases, representing what is called a "demographic bonus". However, with the transition moving into the third phase of population aging, the authors also indicate that the bonus would be reversed, with less savings and lower growth.

Due to the demographic transition and consequent change in the behavior of individuals, consumption is strongly reduced. As can be seen in Table 5 , there is a 5.6\% decline in aggregate consumption from 2013 to 2040. In subsequent years, the decline is even greater, so aggregate consumption in 2080 is 14.2\% lower than that observed in 2013.

Regarding social security, the result of the model indicates that retirement expenses would be raised by 66\% from 2013 to 2040 and 124\% by 2060 . On the other hand, revenues would fall by $3.7 \%$ and $11 \%$, respectively. As a result, the social security deficit would increase from the current $3.8 \%$ of GDP to $11.7 \%$ in 2040 and $20.3 \%$ in 2060.

Tax revenues show a more pronounced reduction than that of the output. This is because consumption accounts for almost half of the Brazilian tax base. In addition, the evolution of the revenues would occur in a different way for each level of government. States revenues have the largest decrease, since they are heavily concentrated in the ICMS, a tax on the consumption of goods.

A second factor is that, according to Table 3, the profile of household consumption tends to change with the aging population, with services accounting for a larger share of consumption. The services are not taxed by the ICMS, but by the ISS.

As the ICMS is predominantly based on the consumption of goods, the state revenue is even more affected, causing a fall of $6.4 \%$ in 2040 and $14.9 \%$ in 2060 . On the other hand, the municipal consumption tax, ISS, shows a less intense reduction, 3.5\% in 2040 and $11.1 \%$ in 2060.

Federal taxes on consumption are levied on both goods and services, which make its collection to show an intermediate behavior between the state and municipal revenues. 
As can be seen in Figure 2, the changes in tax collection due to demographic transition tend to increase the share of federal and municipal revenues and to reduce the share of state revenues in the total collected.

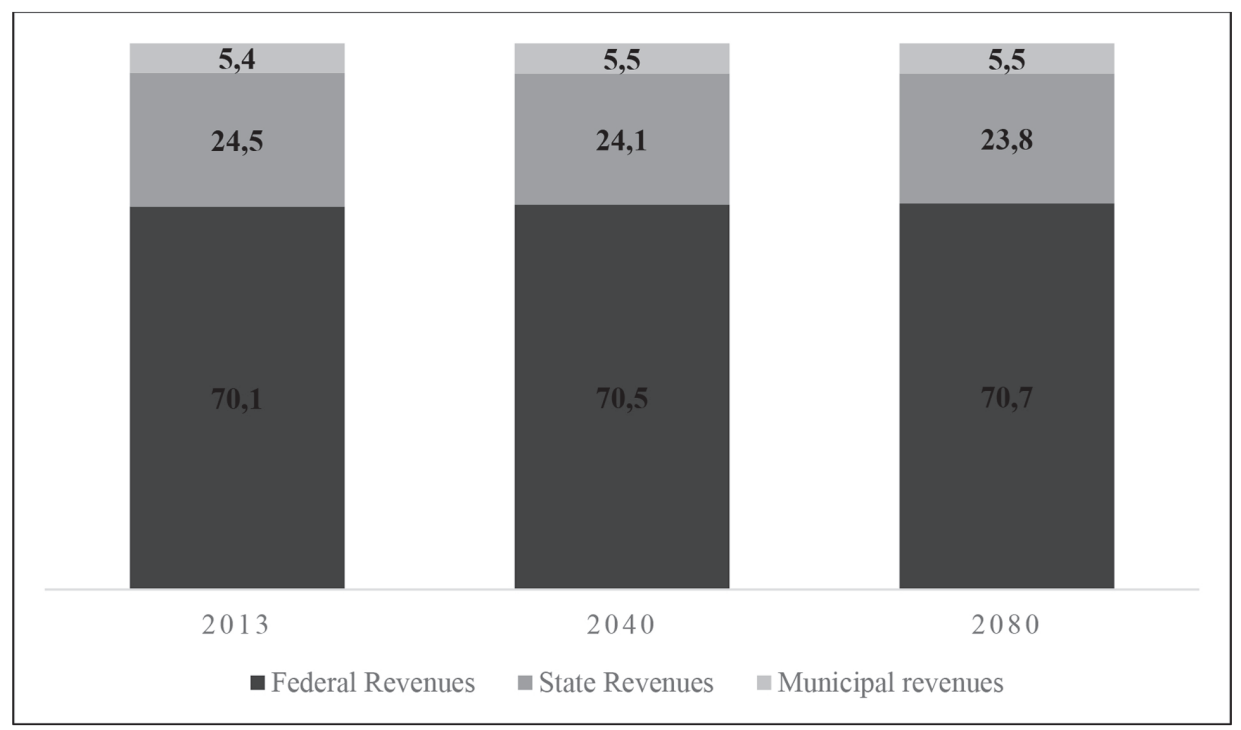

Figure 2 - Distribution of Revenue between Government Levels (\%)

Source: Authors' Elaboration.

Thus, it can be observed that the process of concentration of tax revenues at the federal level in the last decades tends to worsen as a result of the ongoing demographic change.

We conducted two other simulations in order to finance the growth of social security expenditure. In both, the tax burden increases to keep the debt/GDP ratio constant: 1) increase in the consumption rate and 2) increase in the social security tax rate. The results are in Tables 6 and 7.

In Table 6, based on 2013, the tax burden on consumption increases by $81 \%$ in 2040 and $107 \%$ in 2060. This change favors revenue of states $(89.5 \%)$ and municipalities (142.1\%), but with reduced impact on the federal government (1.6\%). For states and municipalities, consumption taxes are prevalent, unlike the federal government, where income tax is more important. Macroeconomic impacts were negative on GDP (-11\%) 
and private consumption (-22\%). This policy, however, is not appropriate. Social security spending is concentrated in the Union, so the debt problem remains.

Table 6 - Impacts of the Demographic Transition on Macroeconomic Variables and Revenues (adjustment on consumption rate)

\begin{tabular}{|c|c|c|c|c|c|}
\hline \multirow{2}{*}{ Variable } & \multirow{2}{*}{$\begin{array}{c}2013 \\
\% \\
\text { GDP }\end{array}$} & \multicolumn{2}{|c|}{2040} & \multicolumn{2}{|c|}{2060} \\
\hline & & $\%$ GDP & S.S* & $\%$ GDP & S.S \\
\hline \multicolumn{6}{|l|}{ Macroeconomic Aggregates } \\
\hline - Output (Y) & 100 & 100 & $-10,1 \%$ & 100 & $-11,3 \%$ \\
\hline - Private Consumption & 60,2 & 54,2 & $-19,1 \%$ & 53,0 & $-22,0 \%$ \\
\hline - Public Consumption & 18,9 & 21,0 & $0,0 \%$ & 21,3 & $0,0 \%$ \\
\hline - Investment & 20,8 & 23,7 & $2,3 \%$ & 24,8 & $5,6 \%$ \\
\hline \multicolumn{6}{|l|}{ Tax Revenues } \\
\hline - Total (including Social Security) & 34,5 & 50,2 & $30,8 \%$ & 53,4 & $37,2 \%$ \\
\hline - Labor Income & 6,6 & 6,6 & $-10,3 \%$ & 6,6 & $-11,5 \%$ \\
\hline - Consumption & 15,3 & 30,9 & $81,7 \%$ & 34,2 & $98,0 \%$ \\
\hline - Capital Income & 5,5 & 5,5 & $-10,7 \%$ & 5,5 & $-11,8 \%$ \\
\hline \multicolumn{6}{|l|}{ Social Security } \\
\hline - Revenues & 7,1 & 7,1 & $-9,6 \%$ & 7,2 & $-10,7 \%$ \\
\hline - Benefits & 10,9 & 24,0 & $97,8 \%$ & 26,8 & $118,1 \%$ \\
\hline \multicolumn{6}{|l|}{ Revenues by Government Units } \\
\hline - Federal Revenues & 24,2 & 27,4 & $1,6 \%$ & 28,4 & $4,0 \%$ \\
\hline - State Revenues & 8,4 & 17,7 & $89,5 \%$ & 19,4 & $105,2 \%$ \\
\hline - Local Revenues & 1,9 & 5,11 & $142,1 \%$ & 5,55 & $159,5 \%$ \\
\hline - tax rate on consumption & 35,0 & 63,6 & $81,2 \%$ & 72,7 & $107,8 \%$ \\
\hline
\end{tabular}

Source: Authors' Elaboration. ${ }^{*}$ percentage change from steady state (2013).

Thus, increasing the social security contribution seems more appropriate for the debt stabilization objective. It is important to remember that in Brazil, social security revenues are not shared with states and municipalities. Table 7 presents the adjustment on the social security tax rate.

In the long run, the social security tax burden increases $320 \%$, negatively affecting macroeconomic variables. However, two issues are addressed in this adjustment: i) government spending - throughout the transition pro- 
cess the budget remains balanced; ii) social security - with the increase in the tax rate, revenue increases and substantially decreases the social security deficit.

Table 7 - Impacts of the Demographic Transition on Macroeconomic Variables and Revenues (adjustment on social security tax rate)

\begin{tabular}{|c|c|c|c|c|c|}
\hline \multirow[b]{2}{*}{ Variable } & \multirow{2}{*}{$\begin{array}{c}2013 \\
\% \\
\text { GDP }\end{array}$} & \multicolumn{2}{|c|}{2040} & \multicolumn{2}{|c|}{2060} \\
\hline & & $\%$ GDP & S.S $\mathbf{S}^{*}$ & $\%$ GDP & S.S \\
\hline \multicolumn{6}{|l|}{ Macroeconomic Aggregates } \\
\hline - Output (Y) & 100 & 100 & $-6,7 \%$ & 100 & $-12,9 \%$ \\
\hline - Private Consumption & 60,2 & 52,4 & $-18,8 \%$ & 50,8 & $-26,4 \%$ \\
\hline - Public Consumption & 18,9 & 20,3 & $0,0 \%$ & 21,7 & $0,0 \%$ \\
\hline - Investment & 20,8 & 27,1 & $21,4 \%$ & 28,2 & $18,2 \%$ \\
\hline \multicolumn{6}{|l|}{ Tax Revenues } \\
\hline - Total (including Social Security) & 34,5 & 49,6 & $34,2 \%$ & 55,0 & $38,8 \%$ \\
\hline - Labor Income & 6,6 & 6,6 & $-6,8 \%$ & 6,6 & $-13,0 \%$ \\
\hline - Consumption & 15,3 & 13,3 & $-18,9 \%$ & 12,9 & $-26,5 \%$ \\
\hline - Capital Income & 5,5 & 5,5 & $-7,3 \%$ & 5,5 & $-13,5 \%$ \\
\hline \multicolumn{6}{|l|}{ Social Security } \\
\hline - Revenues & 7,1 & 24,3 & $218,7 \%$ & 30,0 & $268,7 \%$ \\
\hline - Benefits & 10,9 & 24,4 & $108,6 \%$ & 28,0 & $123,6 \%$ \\
\hline \multicolumn{6}{|l|}{ Revenues by Government Units } \\
\hline - Federal Revenues & 24,2 & 37,6 & $45,0 \%$ & 42,9 & $54,4 \%$ \\
\hline - State Revenues & 8,4 & 8,9 & $-0,8 \%$ & 9,0 & $-6,9 \%$ \\
\hline - Local Revenues & 1,9 & 3,08 & $51,1 \%$ & 3,14 & $44,2 \%$ \\
\hline - tax rate on social security & 11,56 & 42,0 & $239,4 \%$ & 55,8 & $320,5 \%$ \\
\hline
\end{tabular}

Source: Authors' Elaboration. ${ }^{*}$ percentage change from steady state (2013).

\section{Conclusions}

Although it is at an early stage in the process of population aging, Brazil must experience its intensification in the future. This process brings relevant changes in society and has received the attention of scholars in recent years. Among these changes, there will be important impacts on the 
macroeconomic variables and, consequently, on the fiscal situation of the country.

With the objective of analyzing these effects, especially on tax collection, the present study made use of a dynamic model of overlapping generations, composed of four sectors: households, firms, governments and social security.

The results suggest a strong reduction of consumption, output and labor, with the investment showing smaller decreases and consumption being the most affected. Social security benefits grow $66.4 \%$ by 2040 and $123.7 \%$ by 2060 .

Revenues fall more than output. The decrease in revenue, however, would occur differently at each level of government. The state collection would have the largest reduction, while the municipal collection would have the lowest loss. Therefore, the changes in tax revenues due to the demographic transition tend to increase the federal and municipal share in the total collected, with a reduction of the share of the States.

Thus, this article is important in understanding the possible effects of structural changes in revenues, such as those influenced by the demographic transition, and may be useful in helping to formulate appropriate policies to address the issue. 


\section{References}

Auerbach, A. J. and Kotlikoff, L. J. "Dynamic fiscal policy”. Cambridge: Cambridge University Press, 1987.

Bloom, D. E.; Williamson, J. G. "Demographic transitions and economic miracles in emerging Asia". The World Bank Economic Review 12, no 3: 419-455, September, 1998.

Bloom, D. E.; Finlay, J. E. "Demographic change and economic growth in Asia". Asian Economic Policy Review 4, no 1: pp. 45-64, 2009.

Broyden, Charles G. "A class of methods for solving nonlinear simultaneous equations". Mathematics of computation, 1965: 577-593.

Cavalcanti, M. A. F. H; da Silva, N. L. C. "Impactos de Políticas de Desoneração do Setor Produtivo: uma avaliação a partir de um modelo de gerações superpostas". Estudos Econômicos 40, no 4: 943-966, out./dez, 2010.

Fehr, H.; Jokisch, S; L, Kotlikoff. "Fertility, Mortality and the Developed World's Demographic Transition". Journal of Policy Modeling 30: 455-473, 2008.

Freitas, Carlos Eduardo de. "Desoneração da folha de pagamentos: Uma aplicação do modelo de gerações sobrepostas para o Brasil”. PhD Thesis, Universidade Federal de Pernambuco, 2015.

INSTITUTO BRASILEIRO DE GEOGRAFIA E ESTATÍSTICA-IBGE. 2013. “Projeções da População - Brasil e Unidades da Federação”. Série. Relatórios Metodológicos, volume 40. Rio de Janeiro. Janeiro.

2014. “Sistema de Contas Nacionais 2010-2013”. Série Relatórios Metodológicos, volume 46. Rio de

Kudrna, G., Tran, C., Woodland, A. "The dynamic fiscal effects of demographic shift: The case of Australia". Australian National University, College of Business and Economics. School of Economics 2014-616, 2014.

Paes, N. L., Bugarin, M.N.S. "Parâmetros Tributários da Economia Brasileira". Revista Estudos Econômicos 36, no 4: 699-720, 2006.

RECEITA FEDERAL DO BRASIL - RFB. 2014. “Carga Tributária no Brasil - 2013 (Análise por Tributo e Bases de Incidência)". Brasília.

Standard \& Poors. "Global Aging 2016: 58 Shades of Gray". New York: Standard \& Poor's, 2016. 


\section{APPENDIX}

Chart 1 - List of services in the POF and corresponding classification in
Complementary Law 116

\begin{tabular}{|c|c|}
\hline POF Goods or Services & Correspondence Comple \\
\hline \multicolumn{2}{|l|}{ Habitation } \\
\hline Services and Fees & 10 - Intermediation and similar services. \\
\hline Housekeeping & $\begin{array}{l}7 \text { - Services related to engineering, archite } \\
\text { tion, maintenance, cleaning, environment, }\end{array}$ \\
\hline Household Repairs & 14 - Services relating to third party goods. \\
\hline \multicolumn{2}{|l|}{ Transport } \\
\hline Urban & 16 - Municipal transport services. \\
\hline Maintenance and accessories & 14 - Services relating to third party goods. \\
\hline \multicolumn{2}{|l|}{ Health care } \\
\hline \multicolumn{2}{|l|}{ Health Plan / Insurance } \\
\hline \multicolumn{2}{|l|}{ Dental Consultation \& Treatment } \\
\hline \multicolumn{2}{|l|}{ Medical consultation } \\
\hline \multicolumn{2}{|l|}{ Medical and outpatient treatment } \\
\hline \multicolumn{2}{|l|}{ Surgery services } \\
\hline \multicolumn{2}{|l|}{ Hospitalization } \\
\hline \multicolumn{2}{|l|}{ Miscellaneous exams } \\
\hline Others & \\
\hline
\end{tabular}

\section{Education}

Regular Courses

Higher Course

Other courses and activities

8 - Education, teaching, pedagogical and educational guidance, instruction,

Others training and personal assessment services of any degree or nature.

\section{Recreation and culture}

Recreations and sports

Others

6 - Personal care, aesthetics, physical activities and similar services.

\section{Personal services}

Hair salon

Manicure and pedicure

6 - Personal care, aesthetics, physical activities and similar services.

Repair of personal items

Others

14 - Services relating to third party goods.

\section{Miscellaneous expenses}

Games and betting

19 - Ticket distribution and sale services and other lottery products, bingo cards, cards, bets or coupons, sweepstakes, prizes, including those arising from capitalization bonds and the like.

Ceremonies and parties

12 - Amusement, leisure, entertainment and similar services.

Professional Services 17 - Technical, administrative, legal, accounting, commercial and similar sup-

Occasional Real Estate Others port services.

9 - Services relating to accommodation, tourism, travel and the like. 